\title{
Economix
}

https://economix.fr/

\section{Unconventional Monetary Policies: A Stock-Taking Exercise}

Document de Travail

Working Paper 2020-3
Christian Pfister

Jean-Guillaume Sahuc 


\title{
UNCONVENTIONAL MONETARY POLICIES: A STOCK-TAKING EXERCISE ${ }^{1}$
}

\author{
CHRISTIAN PFISTER AND JEAN-GUILLAUME SAHUC
}

\begin{abstract}
This paper takes stock of the literature on unconventional monetary policies, from their implementation to their effects on the economy. In particular, we discuss in detail the two main measures implemented in most developed economies, namely forward guidance and large-scale asset purchases. Overall, there is near consensus that these measures have been useful, although there are a few dissenting views. Because unconventional monetary policies have left their mark on economies and on the balance sheets of central banks, we offer insights into their legacy and ask whether they have led to a change in "the rules of the game" for setting interest rates and choosing the size and composition of central banks' balance sheets. Finally, we discuss whether to modify the objectives and the instruments of monetary policy in the future, in comparison with the pre-crisis situation.
\end{abstract}

JEL: E52, E58.

Keyword: Unconventional monetary policies.

\section{INTRODUCTION}

While the impact of the 2007-08 financial crisis, also known as the global financial crisis (GFC), was first felt in financial markets, it rapidly spread to the real economy. Across all countries, output and inflation dropped sharply (Figure 1, panels A and B). Central banks reacted by increasing massively their liquidity provision to the banking sector and by lowering interest rates aggressively (see Figure 1, panel C). Once interest rates got close to zero, they resorted to unconventional monetary policies (UMPs), in the face of flagging economic growth and deflationary risks (Drumetz et al., 2015). These measures were essentially of two types.

First, central banks gave forward guidance (FG), meaning that they provided information about their future monetary policy intentions, based on their assessment of the outlook for price stability. This was not a completely new tool, since some central banks had already provided guidance before the GFC either on a regular basis (e.g. the Reserve Bank of New Zealand since 1997), as part of an

\footnotetext{
${ }^{1}$ C. Pfister: Banque de France, 31 rue Croix des Petits Champs, 75049 Paris, France (e-mail: christian.pfister@,banquefrance.fr), Paris 1 Panthéon Sorbonne and Sciences Po. J.-G. Sahuc: Banque de France, 31 rue Croix des Petits Champs, 75049 Paris, France (e-mail: jean-guillaume.sahuc@banque-france.fr) and University Paris-Nanterre. This paper was prepared for the special issue of the Revue d'Economie Politique on unconventional monetary policies. We are grateful to Béatrice Saes-Escorbiac and Aurélie Tollet for research assistance. The views expressed in this paper are those of the authors and should under no circumstances be interpreted to reflect those of the Banque de France or the Eurosystem.
} 
inflation targeting framework, or on an occasional basis (e.g. the US Federal Reserve - Fed, between August 2003 and December 2005). What was new was that, as policy rates were stuck at very low levels, central banks extensively used communication about future monetary policy intentions to enable the private sector to have a clear understanding of how borrowing costs would likely develop in the future.

Second, central banks purchased large quantities of assets in order to put downward pressure on long-term interest rates (see Figure 1, panel D). These large-scale asset purchases (LSAPs) were not new either. The Bank of Japan had already implemented such measures since the early 2000s, following the bursting of house and stock price bubbles and the ensuing crisis in the Japanese banking sector.

\section{Figure 1. Key Figures for the United States, Euro Area, United Kingdom and Japan}
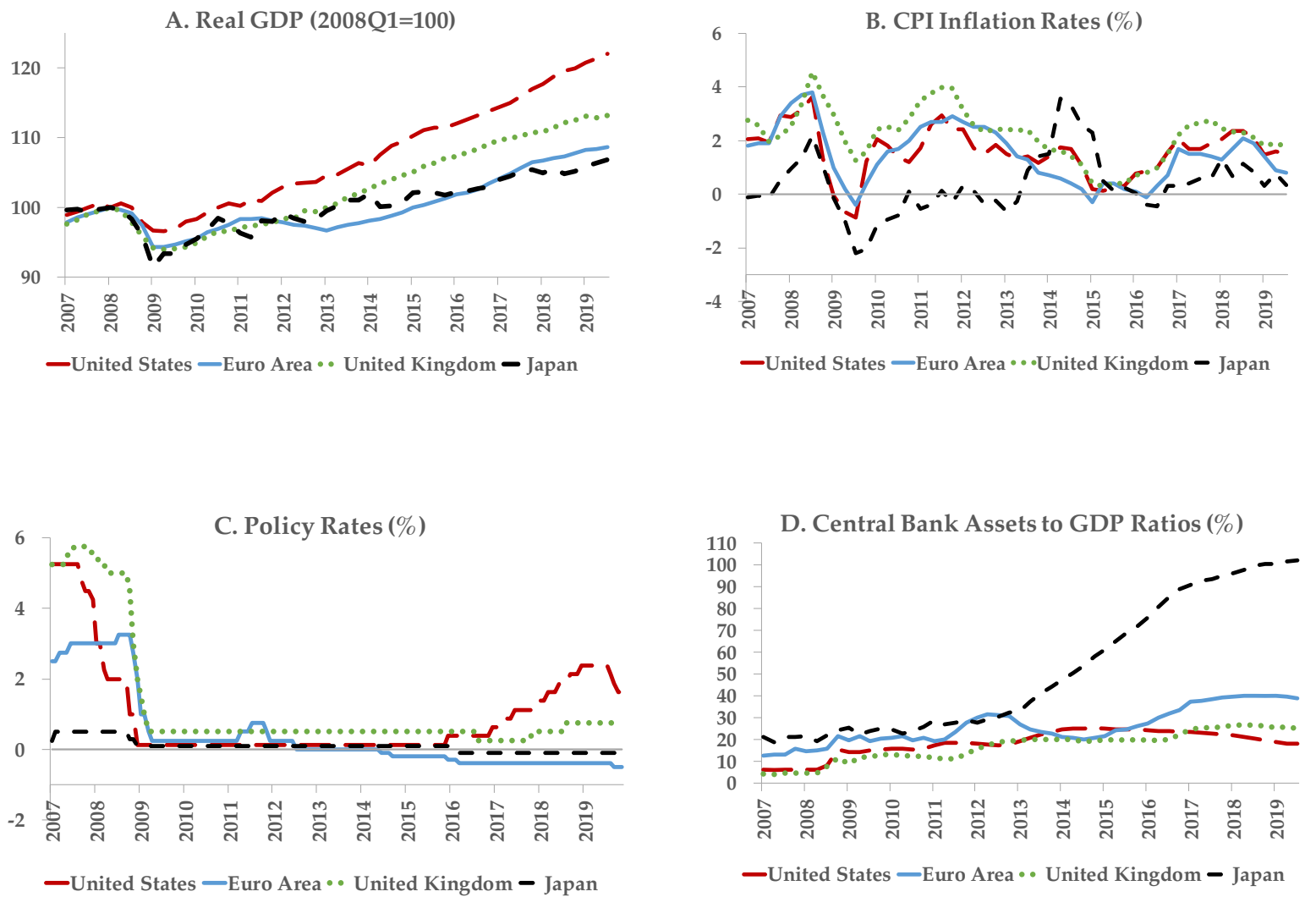

Sources: Thomson Reuters, Fred Database (St Louis Fed), and ECB Statistical Data Warehouse.

Central banks also entered uncharted territory. They refinanced non-banks (Fed), broadened the scope of assets they accepted as collateral (European Central Bank - ECB), extended the maturity of their refinancing (ECB, Bank of England - BoE), and allocated liquidity at fixed rates in virtually 
unlimited amounts (ECB). They also granted rebates on interest rate conditions conditional on the granting of credit (ECB, BoE), lowered interest rates below zero (Danmarks Nationalbank, ECB, Sveriges Riksbank, Swiss National Bank and Bank of Japan - BoJ), and started controlling longterm interest rates $(\mathrm{BoJ})$.

However, ten years after the most acute phase of the GFC, UMPs had generally not started to be unwound at the end of the 2010s, with the Fed being an exception, and growth had remained sluggish and inflation below target in the euro area and Japan. Furthermore, the Covid-19 pandemic recently prompted renewed lender-of-last resort interventions and asset purchases by central banks in order to ease financial constraints.

The objective of this article is to provide a review of the main issues related to unconventional monetary policies, distinguishing whether they relate to the past, the present or the future, so as better understand the contributions and limits of these new tools. First, the two main measures which have been implemented in most developed economies, namely forward guidance and large-scale asset purchases are discussed in details. Second, because these policies have left their mark on economies and on the balance sheets of central banks, we offer insights into their legacy and ask whether "the rules of the game" for setting interest rates and choosing the size and composition of central banks' balance sheets have changed because of the implementation of UMPs. Third, we discuss whether to modify the objectives and the instruments of monetary policy in the future, in comparison with the pre-crisis situation.

\section{THE PAST}

In line with previous surveys (see e.g. Bhattarai and Neely, 2018, Drumetz et al., 2015, Dell'Ariccia et al., 2018, Kuttner, 2018), we focus principally on the two main UMP measures mentioned above: forward guidance (FG) and large-scale asset purchases (LSAPs), which have been implemented in most developed economies. ${ }^{2}$ We also devote a specific section to the ECB's responses to the sovereign debt crisis. Overall, there is near consensus that UMPs have been useful, although there are a few dissenting views. This is important both because UMPs have a bearing on present monetary policies (there is a "legacy" of UMPs), and because UMPs could be used again in the future.

\footnotetext{
${ }^{2}$ Most of these surveys also consider the adoption of negative interest rates (NIRs) as an UMP. We do not subscribe to this view, since NIRs constitute a standard instrument (a short-term interest rate under the control of the central bank). Furthermore, NIRs have remained above the effective lower bound (ELB, i.e. the rate at which agents substitute cash for deposits, which is below zero as a consequence of the costs involved in such a substitution), and have fed through to financial markets and the broader economy. However, we discuss issues related to ultra-low - including negative interest rates in subsequent sections.
} 
2.1. Forward guidance. The central bank provides broadly defined FG when it communicates about future monetary policy settings (Svensson, 2015). This can apply both to the policy rate and to the balance sheet of the central bank (refinancing and LSAPs). In a narrower sense, FG applies only to interest rates. Following Campbell et al. (2012), FG can be implemented in two different ways: in Odyssean FG, the central bank publicly commits to a future action; in Delphic FG, it merely forecasts macroeconomic performance and likely monetary policy actions. In both cases, in order to be useful, FG has to add information over and beyond the other tools of communication the central bank uses (e.g. publication of the central bank's economic forecasts), and Odyssean FG is more likely to achieve that goal, provided it is credible.

However, Odyssean FG faces several challenges. From an empirical point of view, central banks do not generally commit to future monetary policy actions (Moessner et al., 2017). Even if central banks did commit themselves, they would have to overcome a time-inconsistency problem. If the anticipated effect of their commitment materialised, they would have an incentive not to honour their commitment when it is supposed to be implemented. Anticipating this abandonment, private agents would not deliver the expected benefits of FG, thus making the commitment useless. From a technical point of view, Odyssean - and credible - FG has implausibly strong effects within rational expectations models. This paradox is referred to as the "forward guidance puzzle" (Del Negro et al., 2015). However, this puzzle can be mitigated by making one of the several following assumptions: (i) discounting the future more heavily (Del Negro et al., 2015, Sahuc, 2016), (ii) partly adaptive expectations (Gertler, 2017), (iii) incomplete markets (McKay et al., 2016; Hagedorn et al., 2019), (iv) the absence of common knowledge about future policies or future fundamentals (Angeletos and Lian, 2018), or (v) "realistic" monetary policy rules (Maliar and Taylor, 2018).

In practice, central banks' use of FG has evolved. They first used it in a qualitative manner, referring to their expectation that interest rates would remain low for "some time" (Fed, December 2008) or for an "extended period" (Fed, March 2009; ECB, June 2013). They then issued "calendar-based statements" with explicit time horizons, while keeping their commitment conditional on economic outcomes (Fed, August 2012; ECB, June 2018). Eventually, some of them (Fed, December 2012; BoE, August 2013) adopted "threshold-based" FG, in which reference is made to a specific unemployment rate, and to inflation forecasts or expectations, as benchmarks to keep interest rates low and, in the case of the BoE, the stock of bonds purchased under LSAPs. However, those benchmarks were not understood by the central banks as triggers and, in particular, the thresholds for unemployment rates were hit without triggering policy adjustments.

Evaluating the effects of FG announcements is difficult for three reasons: (i) they were made in conjunction with the announcement of LSAPs, (ii) there have been changes in their formulation and (iii) ex post, a counterfactual should be provided to assess whether the central bank actually deviated from its past reaction function (Bletzinger and Wieland, 2017, provide evidence that this 
was the case for the ECB). Furthermore, outcomes are mixed. Filardo and Hofmann (2014) find that FG does not appear to have had an effect on the level of interest rates, but has led to lower volatility. These results are confirmed by Sinha (2015), also for moments higher than two (skewness and kurtosis), in the case of the United States. In addition, Smith and Becker (2015) distinguish the effects of FG according to its formulation. They find that FG has been effective in lowering expected short-term rates when it was qualitative or date-based, but not when it became conditional. Using a vector auto-regression (VAR), they also find FG surprises effects on employment and prices of similar sizes to those of conventional monetary policy measures.

2.2. Large-scale asset purchases. The central bank adopts a LSAP programme when it announces it will buy a given amount of long or medium-term securities, usually issued by the government, within a given timeframe. The programme can also be open-ended, in which case the central bank usually mentions the pace at which it will conduct its purchases and under which circumstances it will consider bringing an end to the programme. As a consequence, LSAPs involve in most cases an increase in the size of the central bank's balance sheet (although the central bank can also sell short-term securities and buy longer-term ones, in an "operation twist"), and systematically the presence of the central bank in markets in which it normally does not intervene. LSAPs are also dubbed "quantitative easing" (QE). Bernanke (2014) famously declared: "The problem with QE is it works in practice, but it doesn't work in theory". Indeed, as LSAPs amount to swapping very short-term liabilities (i.e. central bank reserves) for longer-term liabilities within the consolidated central bank/government balance sheet, they should have no effect on financial markets and the broader economy in a frictionless world. However, the presence of market imperfections, reflecting risk aversion, regulatory constraints, preferred habitats or market practices, gives rise to imperfect substitutability and term premiums, creating a portfolio balance channel. As the supply of some of the most sought-after securities is restricted, their yields fall and private agents both benefit from wealth effects and reshuffle their portfolios towards riskier assets, facilitating the financing of the economy. Furthermore, LSAPs can support FG through a signalling channel, given that it is very unlikely that the central would raise interest rates while it is purchasing assets.

There is near consensus that LSAPs have been effective in influencing both financial markets and the broader economy (see for instance Dell'Aricia et al. (2018) who provide a review of the evidence on the effects of unconventional monetary policy actions by the ECB, the BoE and the BoJ). Regarding the impact on financial markets, the evidence is largely based on event studies, which assess by how much longer-term yields move shortly after the announcement of a LSAP programme, based on the assumptions that the announcement was unanticipated and that it was not interpreted as a sign that the central bank foresees a slowdown in economic activity. In the case of the Fed's LSAP programmes, the first (QE1), announced in November 2008, is credited with a negative effect of around 100 basis points on 10-year Treasury interest rates, while the cumulative 
impact of the four programmes (QE1, QE2, Maturity Extension Programme and QE3) is reckoned at above 150 basis points on the same benchmark (Gagnon et al., 2011; Krishnamurthy and VissingJorgensen, 2011; Bauer and Neely, 2014). However, event studies have been criticised. Greenlaw et al. (2018) find many days on which Fed news, in the form of FOMC announcements, release of minutes and policy-related speeches by the Fed Chair, was associated with a reversal of some of the bond market movement that occurred on the announcement days. Furthermore, according to Thornton (2017), only one of the 53 Fed announcements considered in the literature on event studies was effective, in the sense that the announcement effects were due solely to QE news and were statistically significant. Nevertheless, LSAPs could still be effective, for instance if they have been anticipated, which is likely to have been more and more the case as the use of the instrument became more common. Indeed, time series analysis of term premiums, which are another way of gauging the impact of LSAPs on long-term interest rates, deliver results that are close to those of event studies (see e.g. Bonis et al., 2017).

Regarding the macroeconomic impact, the literature is relatively scarce. There are papers that use VAR models (e.g. Baumeister and Benati, 2013, Weale and Wieladek, 2016, Wu and Xia, 2016) and others that employ DSGE models (e.g. Chen et al., 2012, Gertler and Karadi, 2013, Engen et al., 2015, Andrade et al., 2016, Sahuc, 2016, Carlstrom and Fuerst, 2017, or Mouabbi and Sahuc, 2019). Some of these papers have used a shadow interest rate, which is unconstrained by the effective lower bound (ELB) on interest rates, as a measure of the overall stance of monetary policy. In feeding a VAR with a shadow rate, Wu and Xia (2016) find that LSAPs reduced the US unemployment rate by a full percentage point from July 2009 to December 2013. Mouabbi and Sahuc (2019) incorporate a shadow rate into a DSGE model for the euro area and show that, without unconventional measures (including LSAPs, but also FG, fixed rate full allotment and longer-term refinancing operations), year-on-year inflation and GDP growth would have been on average about $0.6 \%$ and $1.1 \%$ respectively below their actual levels over the 2014-2017 period.

Nevertheless, LSAPs raise a number of issues, inter alia:

- Why not just let the Treasury reduce the duration of its debt by adjusting the maturity mix of new issuances (Greenwood et al., 2016)? One possible objection is that the Treasury would then be submitting itself to a tight liquidity constraint. However, such Treasury debt management would increase the effectiveness of LSAPs, because it would eliminate the possibility that the Treasury undercuts the central bank's LSAPs by increasing the maturities of its issuances, as the US Treasury seemingly did (Hamilton and Wu, 2012 and Greenwood et al., 2016). Furthermore, submitting fiscal policy to a strict liquidity constraint would not necessarily be very binding in times of crisis, since the demand for safe assets is then particularly great, as long as public debt is seen as sustainable (Caballero et al., 2017). Finally, as underlined by Greenlaw et al. (2018), debt management would then naturally play a 
counter-cyclical role.

- In most cases, LSAPs are conducted by buying public securities in the secondary market. This is costly: Breedon (2018) estimates the cost of government issuance and central bank purchases amounts to about $0.5 \%$ of the total value of the LSAPs conducted by the Bank of England. So why does the central bank not buy directly from the Treasury, aside from legal reasons, such as the prohibition of so-called "monetary financing" in the Maastricht Treaty? $?^{3}$ Provided the central bank acts on its own initiative, the possible objection that prices may then be biased does not seem to hold since, when the central bank conducts LSAPs, this should in principle be reflected in market prices even if purchases are made in the secondary market, and this is precisely what the central bank is aiming for.

- Do LSAPs have persistent effects and if so, why? Swanson (2017) finds that the effects of the Fed's LSAPs are persistent when the QE1 announcement is excluded from the estimation sample, and proposes to discount that event as the announcement took place at a time when financial markets were functioning very poorly. That the effects would be highly persistent also squares well with the observation that the effects of LSAPs appear for the most part on announcement rather than when the purchases are actually conducted, and thus that it is the stock of securities held by the central bank, not the flows, that matters. Coeuré (2018a) also explains that LSAPs can create scarcity effects on public bond markets, which make their effects persistent. However, these two stories do not necessarily fit with an expected "unwinding". Indeed, the 10-year term premium on Treasuries did not react when the Fed announced in September 2017 that it was starting to deplete its portfolio of securities (Figure 2), as if investors had anticipated that the Fed would not deliver on its commitment, for instance because it would soon have to carry out new LSAPs.

- Are LSAPs beggar-thy-neighbour policy instruments? Bauer and Neely (2014) and Neely (2015) show that the Fed's LSAPs significantly influenced bond yields in developed countries, thereby supporting their economies, but that they also contributed to the depreciation of the dollar, especially in the case of QE1. However, those effects were not substantially different from those of previous equivalent US monetary policy shocks. There were nonetheless protests from emerging countries, with President Rousseff of Brazil declaring in 2012 "quantitative easing policies (...) have led to a currency war and have introduced new and perverse forms of protectionism in the world". Partly confirming that view, Fratzscher et al. (2016) find that the Fed's LSAPs seem to have increased the pro-

\footnotetext{
${ }^{3}$ Strictly speaking, Article 123 of the Maastricht Treaty does not prevent the ECB from granting "monetary financing" to euro area Member States (i.e. holding assets issued by them); it just prevents the ECB from granting credit directly to them or purchasing securities issued by them in the primary market.
} 
cyclicality of funds outside the United States, particularly emerging market equities, but this has affected more the composition of fund flows into emerging markets than the total volume.

- Can yield curve control (YCC) be a substitute for LSAPs? Ideally, this could be the case, with YCC being even superior to LSAPs provided it is credible, since the central bank would then not have to engage in any transactions. However, this does not seem to be the view of the Bank of Japan. Indeed, the central bank has maintained its LSAP programme since it adopted YCC in September 2016, although it then also gave itself more flexibility in the amounts and composition of the public securities it would buy.

\section{Figure 2. Breakdown of 10-Year Zero Coupon Yields in the United States and Eonia Swaps (percent)}
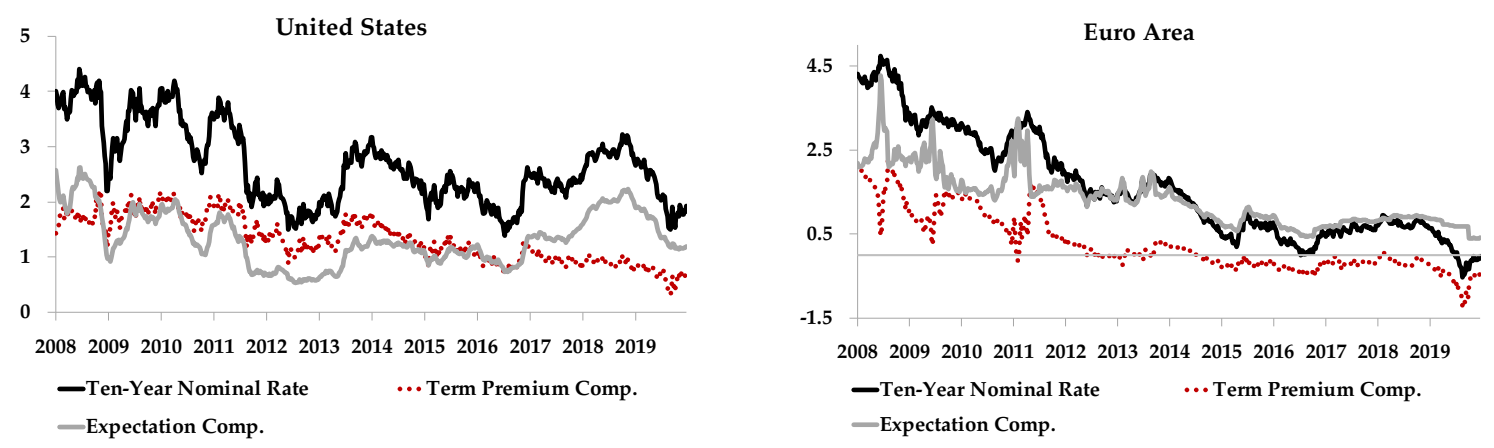

Sources: Bloomberg and Banque de France.

2.3. The sovereign debt crisis and ECB responses. At the end of 2009, the publication by the newly formed Greek government of a much higher than previously estimated yearly public deficit created fears of default. This was the trigger for the euro area sovereign debt crisis, as concerns about the sustainability of public debt led to a sharp increase in interest rate spreads vis-à-vis German Bunds in some peripheral countries. Furthermore, concerns emerged that the banking sector in those countries may have to be bailed out as it held large amounts of both securities issued by their sovereigns, and mortgages at a time when house prices were plummeting. Adjustment programmes were launched in stressed countries, in some cases with the financial support of the International Monetary Fund and the European Commission.

However, as interest rate spreads kept increasing, the ECB engaged in several purchasing programmes to preserve the monetary transmission mechanism and ultimately the integrity of the euro area (see also Hartmann and Smets, 2018, for details on the ECB's policy responses). These programmes were the Securities Market Programme (SMP), which was activated in two waves (from May 2010 to January 2011 and from August 2011 to July 2012). They consisted essentially of public 
bond purchases, the Covered Bond ${ }^{4}$ Purchase Programme (CBPP), which was announced in May 2009 and was aimed at easing funding conditions for credit institutions and enterprises, and the Outright Market Programme (OMT), launched in September 2012, after President Draghi had stated in July that the ECB would do "whatever it takes" to save the euro. The SMP totalled some EUR 220 billion, although no schedule or projected amounts of purchases were released. The CBPP was launched with the aim of purchasing EUR 60 billion worth of assets. The OMT, which was open-ended, unlimited and conditional (the government of a country wishing to adhere to the programme had to comply with an adjustment programme set by the European Financial Stability Facility (EFSF) or the European Stability Mechanism (ESM)), has so far involved no purchases. Both the rationale and the modalities of these programmes make them specific in comparison with LSAPs (Drumetz et al., 2015).

There is broad agreement that overall the ECB programmes were effective in easing sovereign spreads, with some variations regarding their estimated respective contributions (Falagiarda and Reitz, 2015, Szczerbowicz, 2015, Gibson et al., 2016, Lhuissier, 2017, Krishnamurthy et al., 2018, De Santis, 2019). However, views differ more regarding the role of the "redenomination risk" (i.e. the risk that a country might exit the euro area and redenominate its liabilities in the new domestic currency) and the eventual impact of programmes on the financing of firms. De Santis (2019) finds that redenomination risk shocks affected Italy and Spain most adversely, with such risk accounting for $40 \%$ and $50 \%$ respectively of Italian and Spanish spreads (the author does not provide estimates for other countries except France). Krishnamurthy et al. (2018) find that the SMP and the OMT, while having considerable effects on yields, contributed to reducing spreads by diminishing redenomination risk only up to $13 \%$, with the main contributions stemming from reduced default risk (37\%) and reduced market segmentation (50\%). Furthermore, according to Durand and Villemot (2016), the order of magnitude of redenomination risk should not be exaggerated, inter alia because the liabilities of some governments (Greece, Portugal) or the banks in their country (Ireland) are governed by English or New York law, thereby making it legally impossible to redenominate them, and thus making exiting the euro area counter-productive. Ferrando et al. (2019) find that the OMT announcement improved SMEs' access to credit as well as the terms of credit, with a lengthening of loan maturities, for firms borrowing from banks with high balance sheet exposure to impaired sovereign debt. The impact on firms' investment and profitability was positive, with however a weaker effect on firm innovation. In contrast, Acharya et al. (2019) find that the OMT programme allowed banks in stressed countries to grant zombie lending, with firms receiving loans using the funds to build cash reserves and creditworthy firms suffering from this credit misallocation, thereby further slowing the economic recovery.

\footnotetext{
${ }^{4}$ Covered bonds are issued by banks and guaranteed ("covered") by loans extended by the issuing bank.
} 


\section{THE PRESENT}

UMPs have left their mark on economies and on the balance sheets of central banks. In this regard, central banks which have had recourse to UMPs may wish to enter, or have already entered in the case of the Fed, a process of monetary policy "normalisation". However, although this process was referred to by the Fed at the 22 June 2011 Federal Open Market Committee (FOMC) meeting, central banks and economists who use the phrase do not clearly define it and refrain from using explicit norms to define "normalisation". Here, "normalisation" refers to:

- Regarding interest rates, maintaining only qualitative forward guidance. For instance, Powell (2019) indicates that the Fed removed the last elements of the crisis-era guidance in January 2019, even though the FOMC still used the word "guidance" in its January statement. He also mentions that the advances in transparency made during the GFC, such as the publication of the FOMC's federal funds rate projections (the "dot plot") will be retained.

- Regarding the central bank's balance sheet, returning to the standard way of implementing monetary policy through the setting of a short-term interest rate controlled by the central bank via refinancing operations, instead of through the remuneration of excess reserves as currently done.

A fundamental reason for normalisation lies in the desire of central banks to give themselves room for manoeuvre before a likely future recession. Furthermore, the effects of UMPs on the economy are much less well understood, thus more uncertain and harder to predict than those of conventional interest rate moves. Central banks can therefore be expected to return to an operational framework that they have known and used for decades when economic signals become positive.

In this context, one may ask whether "the rules of the game" for setting interest rates and choosing the size and composition of central banks' balance sheets have changed because of the implementation of UMPs. ${ }^{5}$

3.1. Interest rates. In the standard description of the monetary transmission mechanism (Drumetz et al., 2015), one can distinguish two steps. In the first, the central bank sets an interest rate for its

\footnotetext{
${ }^{5}$ We do not discuss the heterodox critique of the setting of interest rates by the central bank that is based on the neoFisherian view. According to this view, monetary tightening that is expected to be permanent leads to an increase in inflation in the short run. Indeed, as explained by Williamson (2016), the nominal interest rate can be expressed as the sum of the real (inflation-adjusted) rate of interest and future inflation. If the central bank increases the nominal interest rate by raising its nominal interest rate target by 1 percent and uses its tools to sustain this forever, these effects dissipate in the long run. After a long period, the increase in the nominal interest rate will have no effect on the real interest rate and will be reflected only in a one-for-one increase in the inflation rate. In this context, proponents of the neo-Fisherian view argue that central banks' policy of keeping interest rates at very low levels for a long period of time can only cause inflation to eventually decline well below their inflation target of $2 \%$.
} 
operations that determines short-term money market rates through arbitrage between operations with the central bank or in the interbank market. In the second, observed and anticipated shortterm interest rates then feed through to the financial system and the economy. The way UMPs may have affected those two steps are examined in turn.

3.1.1. Controlling short-term interest rates. As central banks engaged in LSAPs, they inflated their balance sheets by creating reserves to pay for their purchases. In turn, the banking sector moved at some point from a "structural liquidity deficit" to a "structural liquidity surplus" (i.e. it no longer needed to be refinanced by the central bank but instead financed it).

Can central banks control short-term interest rates in a situation of structural liquidity surplus? In principle, they can, conducting reverse repurchase operations (RROs) within a "corridor system" (i.e. the central bank has an upper and lower band for the market interest rates it wants to target) as that operated by the European Central Bank, just as they control short-term interest by conducting repurchase operations in a situation of structural liquidity deficit: the management of a corridor system is symmetric. However, the size of RROs can become too large in comparison with the overall size of the repurchase market, and the central bank may then prefer to operate a "floor system", in which the rate of remuneration of reserves sets the floor for money market rates. In fact, since the introduction of the remuneration of reserves by the Fed in October 2008 (Bech and Klee, 2011) until April 2019, the fed funds rate has been below the rate of interest on reserves (IOR) (Figure 3). In the euro area, the launch of the Asset Purchase Programme (i.e. the ECB's LSAPs) in March 2015 marked a fundamental change in euro area money markets as unsecured trading volumes dropped, interbank rates decreased towards the deposit facility rate (DFR) and secured as well as unsecured non-bank to bank rates started to trade below the DFR (Figure 3).

Figure 3. Target Rates, Facility Rates and Repo Rates in the United States and the Euro Area (percent).
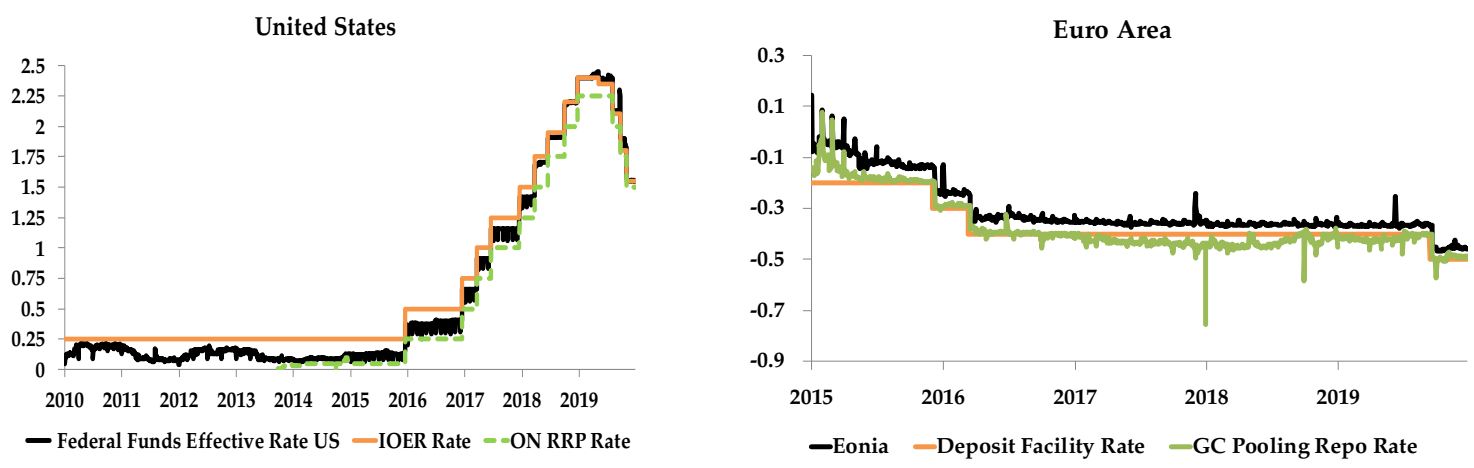

Sources: Bloomberg and New-York Fed. 
In the United States, a fed funds rate below the IOR partly reflects institutional factors as some economic agents (Government Sponsored Enterprises - GSEs) are allowed to have accounts with the Fed but not to receive interest on reserves. Those agents, who permanently have liquidity surpluses to invest, lend to banks, who in turn earn the IOR (Armenter and Lester, 2017). However, arbitrage is not strong enough to close the spread between the fed funds rate and the IOR, which thus acts as a ceiling rather than a floor to the fed funds rate. In both areas, market imperfections such as bargaining power, reflecting the concentration of money market transactions, or regulatory factors, such as leverage and liquidity requirements, may also be at play to prevent full arbitrage (Coeuré, 2018b; Potter, 2018). In any case, recent changes in IOR were followed by very similar changes in money market rates, thus the control of short-term interest rates by the Fed does not seem to be in question. However, the current situation resembles that which would prevail in a world without money, where agents would use securities both to settle transactions and as stores of value (Friedman, 1999). In such an environment, interest rate control could still be exercised by the issuer of the legal unit of account, which would remunerate it at a rate providing a ceiling to short-term interest rates, since there would be no spontaneous demand for it (Woodford, 2001). To the extent that the central bank is ready to "phase out" or "unwind" (i.e. to progressively reduce its portfolio of securities), the current situation should nevertheless be temporary, as the amount of reserves should decline, pushing short-term interest rates above the rate of remuneration of reserves (Bech and Klee, 2011).

3.1.2. The transmission of policy rates to the economy. Setting policy rates at unprecedentedly low levels and adopting UMP measures which put downward pressure on longer-term rates overall resulted in low and flat yield curves. Several commentators stress that ultra-low interest rates are detrimental to the macro-economy. Their main arguments are that persistently low interest rates - and in particular negative nominal interest rates (NIRs) (i) encourage "search for yield" strategies, with the risk of increasing the number of non-performing loans (NPLs) ${ }^{6}$, (ii) erode the profitability of banks as low rates are typically associated with lower net interest margins, (iii) and, as a result, contribute to reducing banks' equity and hence weigh on banks' supply of loans. These arguments are assessed in turn.

Do ultra-low interest rates increase non-performing loans (NPLs) and encourage risk-taking? Figure 4 plots the recent dynamics of the NPL ratio (defined as the share of NPLs on total loans) in the countries that implemented negative rates, as well as for the United States. One can observe an upward trend in the NPL ratio from 2008 to 2013 for the euro area and Denmark, while this ratio is constant for Sweden and Switzerland. However, the NPL ratio started to decline from 2014

\footnotetext{
${ }^{6}$ A non-performing loan is defined as (i) a loan that is in arrears for more than 90 days (principal and/or interest), (ii) a loan that is unlikely to be repaid without collateral being realised.
} 
in the euro area and Denmark, in parallel with the implementation of negative deposit facility rates. In fact, the decline of NPL ratios was an intended consequence of a very accommodative monetary policy stance, which contributed to a lowering of interest payments and to a reduction the default risk of borrowers, thanks also to general equilibrium effects/higher aggregate demand. However, if banks take on too much risk, because of low interest rates/search for yield strategies, this shortterm reduction of NPLs may mask a future increase. Loans of bad quality would under-perform in a few years' time, especially when interest rates start to increase. So far, there have been no signs of such developments. One can also note that the NPL ratio has been steadily decreasing since 2008 in the United States. Over the seven years during which UMPs were conducted in the United States, there was no clear sign of excess risk-taking resulting in an increase in NPLs.

\section{Figure 4. Non-Performing Loans Ratios and Policy Rates (percent).}
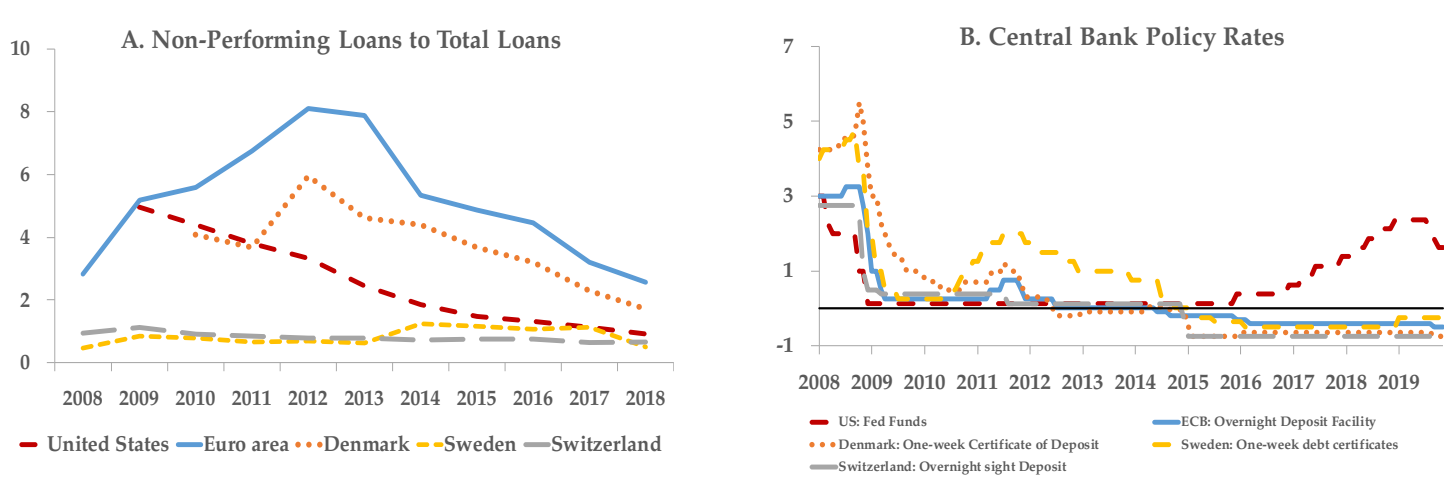

Sources: World Bank (WDI), and Thomson Reuters.

A related issue is whether a prolonged period of low interest rates might produce overconfidence in economic agents, (i) increasing dramatically their risk tolerance and (ii) contributing to financial imbalances. This mechanism, referred to as the risk-taking channel of monetary policy, can have long-lasting adverse consequences for economic activity in case it is neglected (see Borio and Zhu, 2012, Fève et al., 2018, among others). The longer the yield curve remains flat, the higher the risks associated with the level of interest rates for the financial sector. In addition, an excessively long accommodative policy may encourage the build-up of leverage and fuel asset price bubbles. With respect to the United States, the evidence reviewed by Kuttner (2018) is reassuring in this regard. As far as the euro area is concerned, Heider et al. (2019) find that banks that rely mainly on deposit funding take on more risk than banks that rely on other funding sources when the policy rate becomes negative. However, they also find that firms that receive loans from those banks appear financially constrained, and do not resemble "zombie" firms. Based on 196 euro-area banks (70\% of total EA loans), Demiralp et al. (2019) also show that banks in the euro area with an overall heavier 
negative interest rate burden - associated with holdings of excess liquidity and the collection of funds from the public - reallocate more towards higher-yielding assets (i.e. loans) in an effort to maintain adequate profitability.

Do ultra-low interest rates affect bank profitability and bank lending in a way that creates asymmetric pass-through? As policy rates approach the zero-lower bound (ZLB) and the room for manoeuvre for banks to decrease deposit rates is reduced, concern has been expressed that there might exist an "economic lower bound" (Coeuré, 2016). This would correspond to the rate at which the detrimental effects on the banking sector outweigh the benefits and further rate cuts risk reversing the expansionary monetary policy stance. When this risk materialises, the "reversal rate" (Brunnermeier and Koby, 2018) would have been reached. Furthermore, as banks engage by nature in maturity transformation (i.e. they borrow at short maturities and lend at longer maturities), the flattening of the yield curve brought about by keeping policy rates "low-for-long" and engaging in UMP measures would also harm banks' profitability, ultimately forcing them to reduce lending. However, the evidence is mixed and so far, both banks' profitability and bank lending have overall remained resilient in countries where interest rates have been ultra-low, although keeping policy rates and/or the slope of the yield curve low during a protracted period does seem to have detrimental effects. Using a sample of 3,385 banks from 47 countries from 2005 to 2013, Claessens et al. (2018) find that a $1 \%$ interest rate drop leads to an 8 -basis-point lower net interest margin, with this effect greater (20 basis points) at low rates. However, the effects on returns on assets (ROAs) are found to be much weaker and not statistically significant. In fact, the relationship of ROA to the slope of the yield curve is more often statistically significant and consistently larger in a low interest rate environment, although the effects of low rates on ROA increase over time, especially in the fourth year. Regarding the euro area, Altavilla et al. (2018) find that the adverse effects of ultra-low rates on net interest margins (NIMs) are largely offset by the positive impact on intermediation activity (increases in fees and in lending) and credit quality (lower loss provisions), both resulting from the improvement in the macroeconomic environment. However, they do not disregard the fact that keeping rates low for a long time might have negative consequences for bank profitability. In that regard, Klein (2020) finds a positive impact of the level of the short-term rate on the net interest margin of euro-area banks, which increases substantially at negative rates. Bank lending might also be hampered once interest rates have reached very low levels, as loan supply is discouraged (Borio and Gambacorta, 2017, using of sample of 108 large international banks), thereby diminishing the effectiveness of monetary policy. Nevertheless, Klein (2020) finds that the negative impact of a falling net interest margin on euro-area bank lending vanished.

Are nominal interest rates, which are negative yet above the ELB, special with regard to the monetary policy transmission mechanism? As policy rates enter negative territory, banks' profitability would be reduced given that they are reluctant to remunerate deposits at negative rates 
for fear of customers' frustration and possible conversion of deposits into cash. Eggertsson et al. (2019) argue that monetary policy transmission is impaired when policy rates enter negative territory because deposit rates are bounded at close to zero. The authors focus on the Swedish experience, and find that once the policy rate reached $-0.5 \%$, the pass-through to lending rates was limited. Moreover, the authors claim that once the floor on deposit rates was reached, the decrease in the policy rate actually had contractionary effects (i.e. led to an increase in lending rates). Their conclusions are based on the bank-lending channel of monetary policy transmission. This channel derives from the fact that when the stance of monetary policy changes, banks can only imperfectly adjust their funding structure and this has consequences for their loan supply. In the specific case of a monetary policy loosening with policy rates entering negative territory, the authors suggest that deposit financing is no longer convenient for banks. This is because deposit rates would be bounded at zero. As banks can only imperfectly adjust their funding structure, the spillover to lending rates and loan growth would thus be limited. But the relevance of the bank lending channel has been called into question since the 1980s, as the regulation of deposit rates has been lifted partially or totally in all developed economies and banks have gained greater ability to substitute deposits with other sources of funding as financial markets have developed. Girotti (2019) empirically confirms this argument in the United States between 1994 and 2008, and finds that the lending channel still exists but its magnitude is limited for the average bank. Based on empirical evidence on the euro area, Levieuge and Sahuc (2020) find that banks usually tend to adjust their lending rates more slowly and not completely in response to monetary policy easing, while they do increase them fairly quickly and by roughly the same proportion in response to a tightening of policy rates. They show in particular that this downward interest rate rigidity is even stronger when policy rates are stuck at their effective lower bound, suggesting that interest rates should be adjusted substantially more when policy rates enter negative territory. One caveat may be that, if policy rates would remain negative for a protracted period, competition would likely force banks to pass these negative rates through to lending rates. Based on the Swedish experience, Erikson and Vestin (2019) obtain even starker conclusions: bank lending rates did decrease when policy rates went negative. They suggest that the pass-through may have become somewhat more gradual and less complete for lending to households, but that negative policy rates do not appear to have distorted the transmission of monetary policy too much. In addition, using data from 5,113 banks from the EU and Japan, with observations for 14 different currencies between 2010 and 2016, Lopez et al. (2018) find that banks' profitability as a whole has, thus far, been unaffected by negative nominal interest rates, especially in countries with floating exchange rates. Consistent with the results of Altavilla et al. (2018), they also find that banks, especially large ones, have been able to offset losses in interest incomes with increases in other income (fees, capital gains, etc.). Furthermore, differences between high and low deposit-ratio banks are found to be only modest. These observations are also broadly in line with 
those of the IMF (2017), according to which, even when some mortgage rates increased somewhat following the adoption of NIRs, as was the case in Switzerland, they quickly corrected thereafter. In this regard, Corbae and Levine (2018) recommend increasing competition in the financial industry in an environment of ultra-low interest rates, in order to avoid perverse reactions to monetary policy decisions, while enhancing bank governance and tightening leverage requirements to avoid weakening the banking sector. Lastly, it is not clear that deposit rates are bounded at zero. Competition favours the transmission of negative interest rates, since banks can offer negative rates to their corporate clientele when the alternatives these depositors have on comparable investments also bear negative rates. This is not the case for households, who can more easily store cash and use it when making transactions. In fact, recent evidence by Altavilla et al. (2019) suggests that some non-financial companies actually see negative interest rates on their deposits.

Overall, monetary transmission channels under NIR policies are conceptually analogous to those under conventional monetary policy, with the exception of the role of cash, and since the adoption of these policies, many of the key financial variables have evolved broadly in line with the standard transmission channels (Arteta et al., 2016). Interestingly, Curdia (2019) examines what would have happened had the Fed adopted a negative interest rate policy during the most recent recession. His findings show that allowing the fed funds rate to drop below zero may have reduced the depth of the recession and enabled the economy to return more quickly to its full potential. It may also have allowed inflation to rise faster towards the Fed's 2\% target. Mouabbi and Sahuc (2019) also show some positive macroeconomic effects when interest rates moved into negative territory (between June 2014 and January 2015) in the euro area. However, their framework does not allow them to quantify the effects of this specific policy after 2015 because other measures were implemented at the same time and it is not possible to break down the total positive effect.

3.2. Central banks' balance sheets. Large holdings of long-term government bonds and private securities expose central banks to interest rate and credit risks. These risks could cause the central bank to make losses, threatening its independence. This raises the following question: to what extent should the central bank unwind? Alternatively, is there an optimal size for the central bank's balance sheet? The latter question seems to make little sense: the two main items on the liabilities side of the balance sheet are currency, the supply of which is demand-led (the central bank cannot refuse to supply banknotes at par in exchange for reserves), and reserves, the level of which is endogenous to monetary policy operations. However, the point has been made that, in order to accommodate the possible demand of banks for high-quality liquid assets (HQLA) resulting from the Basel III liquidity regulation, ${ }^{7}$ central banks could and perhaps should keep a large amount of reserves on

\footnotetext{
${ }^{7}$ The Basel III liquidity regulation creates two requirements. The Liquidity Coverage Ratio (LCR) requires that banks have an adequate stock of unencumbered HQLAs that can be converted easily and immediately in private markets into
} 
their balance sheets (Duffie and Krishnamurthy, 2016, Greenwood et al., 2016, Logan, 2018). Greenwood et al. (2016) claim that large central bank balance sheets could be a tool for enhancing financial stability because, in times of financial stress, central banks' provision of safe, liquid securities to market participants in the form of bank reserves should be effective in preventing panic. However, this argument in favour of the central bank playing the role of lender of last resort only implies that the central bank's balance sheet could be large in times of financial stress, and not permanently. Reserves could also help to make up a shortage of safe assets (Caballero et al., 2017). The issue would then be which assets the central bank should hold, and the answer should be based on the achievement of monetary policy objectives, rather than greater comfort in implementing monetary policy, be it from the point of view of the central bank or that of its monetary policy counterparties. In other words, if the central bank wishes to implement an as market-neutral as possible monetary policy, and avoid weighing on risk premiums, it should hold Treasury bills, as the Fed did until 2008. Furthermore, when the central bank purchases safe assets, it does not add to the amount of safe assets or HQLAs, since it withdraws through its purchases the same amount of them as it supplies through the increased provision of reserves (conversely, it takes on risk when it purchases assets which are less safe). On the other hand, there can be interplay between monetary policy and liquidity regulation, as the latter might lead to a steepening of the front-end of the yield curve on a permanent basis (BIS, 2015). Nevertheless, it is doubtful that the central bank should offset that steepening by running a more stimulating monetary policy as it would then undo, at least partly, the effects of prudential policy. Liquidity regulation might also lead to more volatile shortterm interest rates (BIS, 2015; Bech and Keister, 2017; Keister, 2019), thereby possibly introducing more short-term uncertainty into the transmission mechanism. Such volatility was experienced in the US dollar money market in September 2019, prompting the Fed to resume its asset purchases, and thus put pressure on long-term interest rates, in order to provide liquidity. However, central banks can use standard instruments to deal with short-term interest rate volatility, such as increasing remunerated reserve requirements, allowing more reserve averaging and narrowing the interest rate corridor they operate (Drumetz et al. 2015). In full recognition of their role as lender of last resort, central banks could also provide liquidity insurance (Goodhart, 2017, Pfister and Valla, 2018), allowing the size of their balance sheets to increase in times of financial stress by providing liquidity to those banks that need it. Lastly, central banks could tolerate more interest rate volatility or even discontinue the practice of targeting a market interest rate and just signal the monetary policy

cash to meet their liquidity needs for a 30-calendar day liquidity stress scenario. The Net Stable Funding Ratio (NSFR) requires that banks hedge their assets of more than one-year maturity with funding the duration of which is at least as long. Both requirements penalise maturity transformation, but the LCR, with its focus on shorter-term maturities, is more likely to affect the functioning of money markets and thus the transmission of standard monetary policy impulses. The LCR has been fully in effect since the beginning of 2019, whereas the NSFR has been progressively implemented since 2018. Furthermore, the leverage ratio, which is part of Basel III capital requirements, discourages arbitrage trading and this is especially the case in money markets, where margins are usually very slim. 
stance through the setting of their policy rate (in that regard, officially, the ECB does not have an operational target). Regarding banks, they have other HQLAs than reserves at their disposal and can create some supplementary ones through securitization. Overall, the onus of complying with liquidity requirements should fall on the banking sector, rather than constrain the conduct of monetary policy.

\section{THE FUTURE}

By conducting UMPs, central banks have changed the way they operate monetary policy and it is not clear whether those changes are permanent or temporary. At the same time, structural changes have also emerged. Among the most prominent of them are the following ones:

- Global inflation has been on a downward trend since the early 1980s, meaning that low unemployment rates no longer drive inflation up through an increase in wages. In other words, the Phillips curve has considerably flattened (Blanchard, 2016; Kiley, 2015), which makes it more difficult to restart inflation after a deflationary shock has occurred. ${ }^{8}$

- A declining trend in the natural rate of interest (defined as the interest rate that is compatible with a stable level of prices) has occurred in the advanced economies (Laubach and Williams, 2016, Holston et al., 2017, Marx et al., 2017). This increases the risk of monetary policy being constrained by the lower bound of interest rates in the future (Gust et al., 2017). ${ }^{9}$

- There has been an extension in central banks' roles and mandates, in particular into the realm of financial stability, accompanied by greater expectations about what central banks can deliver, on top of price stability: low unemployment, financial stability, lesser inequalities, "responsible" growth, etc. This extension contributes to making monetary policy the "only game in town" (Rajan, 2012).

Depending also on the extent to which central banks will "normalise" the conduct of monetary policies, these changes may have consequences in the future both for the objectives and for the instruments of monetary policy. In fact, commenting on the results of two surveys conducted between February and May 2016, of 95 heads of central banks (with a response rate of 58\%) and

\footnotetext{
${ }^{8}$ Core inflation has been persistently low in several countries, especially in the euro area, despite an economic recovery over recent years. This "missing inflation" episode has often been attributed to a broken Phillips curve. Abdih et al. (2018) explain that this phenomenon stems from the strong persistence of euro area inflation. When using a standard Phillips curve that relates inflation to economic slack, past inflation and expectations about its future readings, the coefficient on past inflation is much higher in the euro area than for the United States. This implies that, following a period of weak demand and low inflation in the euro area, it will take a much longer period of strong demand to get inflation back to the inflation objective. Regarding the United States, Jorda et al. (2019) show that, in the years since the Great Recession, inflation has been driven primarily by public expectations of future inflation rather than by economic slack.

9 The literature attributes the decline in the natural rate to the slowing of potential output, which, in turn, reflects structural factors such as population ageing, slower productivity growth, elevated debt levels, and the damage done by the Great Recession to the labour force and productivity.
} 
401 economists (with a response rate of just below 40\%), Blinder et al. (2017) find that:

- Regarding objectives for central banks, the two changes most frequently discussed, both within central banks and externally, are adding a financial stability objective to the mandate and changing the inflation target, with the second change mentioned mostly by economists.

- Regarding instruments, more than $70 \%$ of governors and $87 \%$ of academics, think that FG is here to stay. Also $41 \%$ of governors and $54 \%$ of them in advanced economies, and $68 \%$ of economists think that LSAPs of government debt should continue.

4.1. Objectives. In this section, we discuss whether the inflation target should be modified and whether, in normal times, financial stability considerations should weigh on monetary policy decisions (see also Blinder et al., 2017). ${ }^{10}$

4.1.1. Should the inflation target be modified? Two possible changes to the inflation target have been suggested: raising it or adopting price level targeting (PLT). In response to the decline in the natural rate of interest, it has been suggested that central banks should raise their inflation target in order to have more leeway to reduce nominal interest rates without hitting the ELB (Blanchard et al., 2010; Ball, 2014). Although this proposal is straightforward, it also raises difficulties. From a theoretical point of view, the ELB is only one reason why central banks target a positive rate of inflation. Among other costs are shoe leather costs, an excessive development of the financial sector, menu costs, distortions arising from the greater difficulty of planning, increased uncertainty, and the slow adjustment process of prices to their optimal level (Drumetz et al., 2015). Those costs would be incurred on a permanent basis if the inflation target were raised. Coibion et al. (2012) study the effects of positive steady-state inflation in New Keynesian models subject to the zero bound on interest rates. For plausible calibrations with costly but infrequent episodes at the zero-lower bound, the optimal inflation rate is low, typically less than $2 \%$, even after considering a variety of extensions, including optimal stabilisation policy, price indexation, endogenous and state dependent price stickiness, capital formation, model uncertainty and downward nominal wage rigidities. In the same vein, Andrade et al. (2019) study how changes in the value of the steady-state real interest rate affect the optimal inflation target, both in the United States and the euro area, using an estimated New Keynesian model that incorporates the zero (or effective) lower bound on the nominal interest rate. They find that the pre-crisis optimal inflation target obtained when the policymaker is assumed to know the economy's parameters with certainty is around 2\% for the United States and around 1.5\% for the euro area. Overall, these results suggest that raising the inflation target is too blunt an

\footnotetext{
10 We discuss neither issues which have recently surfaced such as changing a price stability mandate into a dual mandate (Debortoli et al., 2018) or the roles redistribution (Sterk and Tenreyo, 2018) or climate change policies (Coeuré, 2018c) should possibly play in conducting monetary policy, nor the issue that has recently resurfaced of fiscal and monetary coordination (Bonam and Lukkezen, 2019).
} 
instrument to reduce efficiently the severe costs of zero-bound episodes. From a more practical point of view, a higher inflation target may be difficult to communicate on for central banks, which have long insisted on their role in preserving price stability and have won the support of the public in pursuing that mission. The example of the Bank of Japan, which has fought over the past 20 years to raise inflation expectations and whose country still experiences a rate of inflation below target, is also discouraging. If a rate of inflation of $2 \%$ for most central banks, and of slightly less in the case of the ECB, is so hard to achieve, then it is difficult to justify credibly a higher inflation target. A possible solution might be for the central bank to seek to keep inflation above target as long as the ELB is not binding, in order to ensure that inflation averages its target over the medium to long term (Kiley and Roberts, 2017). Such an approach would avoid raising the inflation target. However, the central bank might come under severe pressure from the public if inflation remains above target for a protracted period. Furthermore, this strategy comes close to PLT without having all its advantages.

Indeed, in contrast to inflation targeting, PLT, whereby the central bank commits to offset deviations from the desired price level with deviations in the opposite direction, has appealing features. It reduces price uncertainty in the medium to long run and it has an in-built stabilisation property (if, following a shock, inflation falls below target, inflation expectations rise and lower real rates, to the extent that the strategy is credible, and vice-versa if inflation rises above target). In particular, as a consequence of the second feature, PLT augments the beneficial effects of forward guidance (Cole, 2018). Although advocated long before the GFC (see e.g. Svensson, 1999), PLT has not been implemented by any central bank in the post-Second World War period, as it is widely seen as difficult to communicate to the public. As a "compromise approach", Bernanke (2017) has suggested central banks could adopt temporary price level targeting. According to that strategy, the central bank would undertake that, in future situations where the policy rate would be at or near zero, the policy rate would not rise before average inflation, since the date at which the policy rate first hits the ELB is at least equal to the target rate. However, Brainard (2017) echoes the remark made above about Kiley and Roberts' (2017) suggestion of targeting average inflation, and notes that the public, seeing elevated rates of inflation in the period during which the average inflation rate rises towards the target rate, may start to doubt that the central bank is still serious about its inflation target.

\subsubsection{Should financial stability considerations weigh on monetary policy decisions in normal times? Financial} instability refers to the size of the cycle when it is defined in terms of changes in asset prices, credit developments and/or changes in the balance sheet structure of agents. Consequently, combating financial instability implies both smoothing the financial cycle and limiting the risk of financial crisis. The debate about whether to use monetary policy to address risks to financial stability, or to 
"lean against the wind" (LAW), has been going on in policy and academic circles for at least two decades. ${ }^{11} \mathrm{LAW}$ refers to an interest rate rule of responding systematically to the financial cycle (in addition to reacting to the real cycle). The majority view, until the GFC, was that monetary policy should respond to fluctuations in asset prices only to the extent that they affect forecasts of inflation or the output gap because (i) the early identification of asset price bubbles was deemed too difficult, and (ii) monetary policy is too blunt an instrument to deal with such price misalignments adequately.

However, not everyone shared this line of argument. Borio and Lowe (2002), Cecchetti et al. (2002) and Stein (2012), among others, called for a more active role for monetary policy in addressing financial stability risks. They notably argue that while low and stable inflation promotes financial stability, it also increases the likelihood that excess demand pressures show up first in credit aggregates and asset prices, rather than in goods and services prices. Accordingly, in some situations, a monetary response to credit and asset markets may be appropriate to preserve both financial and monetary stability. Smets (2014) also explains that financial stability must be a concern for central banks because there is a risk of financial dominance, i.e. a situation that arises when the financial sector is unable to absorb all of its losses, with the risk of cascading defaults if the financial sector is not bailed out.

Adrian and Liang (2018) emphasise the importance of considering the risk-taking channel in costbenefit analyses, because it is a collateral effect of interest rate policies. When the yield curvelowers, intermediaries are induced to engage in risk-taking behaviour. Accordingly, too low interest rates for too long may encourage excessive leverage in risky assets, which puts financial stability at risk. Indeed, when the risk-free rate lowers, short-term liabilities - such as repos or ABS commercial paper become attractive money-like assets that can be used by intermediaries to finance long-term risky positions. In turn, an increase in demand for long-term risky assets lowers yields and spurs aggregate demand. However, in the event of a crisis, abrupt collective deleveraging by "fire sales" to repay short-term liabilities leads to severe financial losses. In this regard, detractors of LSAPs argue that they generate more risk-taking than other unconventional policies because LSAPs not only lower the yield curve but also increase reserves, expanding the ability of intermediaries to acquire risky assets by issuing money-like liabilities. Moreover, LSAPs directly decrease risk-premiums, leading economic agents to underestimate the risk in the economy. However, Woodford (2016) argues that LSAPs increase financial stability risks less than other interest rate policies. His explanation relies on three main arguments. The first one is that, in contrast to other policies, LSAPs reduce the "money premium" of money-like assets - not the rate of return on safe assets directly. Woodford's second argument is that LSAPs are typically implemented when the interest rate has already fallen

\footnotetext{
11 We do not discuss the "cleaning up" view, i.e. reacting to the financial cycle only in the event of a crisis, since this strategy, which creates moral hazard, finds few supporters nowadays.
} 
to the level of the interest paid on reserves, which indicates that reserves are already in excess supply. Finally, Woodford mentions that the reduction in the return on risky long-term assets, when the risk-free interest rate does not move, makes investing in risky positions less attractive, which eventually contributes to reducing financial instability risks.

Levieuge (2019) provides a survey of the evaluations of LAW (especially with DSGE models) from 2008 and concludes that the optimality of LAW is sensitive to the model used. As expected, the nature of financial frictions, the loss function of the authorities, the financial variable included in an augmented Taylor rule, the uncertainty about the effects of financial frictions and the effects of monetary policy on these frictions, are all factors that influence the optimal rule. Based on existing representative empirical estimates and reasonable assumptions, the finding is that the costs of LAW exceed the benefits by a substantial margin. The reason is that the empirical policy rate effects on the probability and magnitude of a crisis are far too small to make the benefits of LAW match the costs. In addition, a LAW strategy seems to raise at least two sources of uncertainty whose consequences are debated. The first uncertainty concerns the equilibrium value of asset prices. An asset price target (or another financial variable) incorporated into a monetary policy rule must be defined by the difference of a financial variable with its equilibrium value. However, there is no clear method for determining this fundamental value in relation to which a valuation or quantity observed would be considered excessive or insufficient. In this context, LAW is costly because it exposes the central bank to a first species risk and a second species risk: to respond to a bubble when there is none, or not to respond when there is one. A second uncertainty relates to the effects of a monetary policy action on the financial cycle. Theoretically, a fall in interest rates should support stock prices, partly due to an increase in anticipated dividends. Nevertheless, what about other asset prices and credit flows? Empirical estimates are rare and can only rely on a small number of observations. They also face a problem of endogeneity as well as a problem of identifying the specific effects, which are attributable to monetary policy.

Another branch of the literature focuses on measuring and comparing the costs and benefits associated with LAW. Lars Svensson has produced a series of in-depth studies on this issue, which are overall unfavourable to LAW. In particular, Svensson (2017) shows that, contrary to the desired objective, LAW generates higher losses in the event of a crisis. In particular, the costs of LAW are not only a weaker economy if no crisis occurs but also, for a given magnitude of crisis, a weaker economy if a crisis occurs. The reason is as follows. Due to the higher interest rates (LAW imposed requirement), the economy in "normal" (non-crisis) times is at a lower equilibrium, with higher unemployment. Under these conditions, the impact of a financial crisis (which cannot be absolutely prevented, including with LAW) will be all the more severe as the economy has already been weakened by LAW.

Kockerols and Kok (2019) evaluate the costs and benefits of LAW using the Svensson (2017) 
framework for the euro area and find that the costs outweigh the benefits. They also find that macro-prudential policy has net marginal benefits in addressing risks to financial stability in the euro area, whereas monetary policy has net marginal costs. This would suggest that an active use ofmacroprudential policies targeting financial stability risks would alleviate the burden on monetary policy to "lean against the wind".

This reinforces the idea that the dominant view in the post-GFC period still prescribes that monetary policy should not respond to financial stability concerns. The new macroprudential framework seems to represent the most effective tool for ensuring financial stability, because it can directly restrain excessive leverage or risk-taking. The literature is thus now focusing on the optimal coordination between monetary policy and macroprudential policy. In addition, should a financial crisis occur, Pfister and Valla (2018) suggest the following framework. First, central banks could offer liquidity support on a standing basis. Second, to limit possible interference with the conduct of monetary policy, the interest rate on the liquidity facility could be set significantly above the policy rate. Third, to avoid a situation where banks in need of liquidity assistance rely on standard monetary policy facilities instead of the liquidity instrument, the list of eligible collateral accepted in the former ones could be narrowed to include only the highest quality instruments, with the overall list remaining unchanged. In addition, central banks should be provided with the appropriate institutional environment so they do not have to play a fiscal role. In particular, putting a limit on how long the central bank can lend a specific institution through its liquidity window could be useful. When that limit is reached, the institution would be taken care of by the resolution fund.

4.2. Instruments. We draw a distinction between UMP instruments that have already been used and other UMP instruments that could be introduced.

4.2.1. Should already used UMP instruments be retained? Use in normal times of FG, LSAPs at or above the effective lower bound (ELB), and yield curve control (YCC) are discussed in turn.

As found by Blinder et al. (2017), the great majority of governors and economists think FG is here to stay and not a single governor mentioned that it should be discontinued. However, whereas economists support more "Odyssean" forms, governors favour "Delphic" forms of FG. In other words, FG is seemingly perceived by central banks to be useful on a permanent basis as a communication instrument, rather than a commitment device. Reasons given by Blinder (2018) include that "transparency is a one-way street" (i.e. once a central bank has moved towards greater transparency, it cannot backtrack, if only because it would be suspected of concealing relevant information) and that Odyssean FG is too complicated to communicate, even with such a supposedly educated public as market participants.

Barring a rise in the inflation target or recourse to so far untested monetary policy measures, there 
is fairly widespread agreement among economists, although less among central bank heads (Blinder et al., 2017), that LSAPs should be used when nominal interest rates reach the ELB. In fact, such a situation may become quite frequent as Kiley and Roberts (2017) estimate that the ELB may be encountered $40 \%$ of the time or more under a rule of the type set out in Taylor (1999). Furthermore, it has been suggested that LSAPs could be a substitute for conventional monetary policy, mainly for financial stability reasons, in order to stabilise "non-fundamental fluctuations in the stock market" (Farmer and Zabczyk, 2016), or because LSAPs would increase risk less than conventional monetary policy (Woodford, 2016) or in the face of financial shocks (Quint and Rabanal, 2017). However, there are not just benefits but also costs to LSAPs, both in normal and crisis times, although the benefits are more likely to outweigh the costs in times of crisis. Among welfare costs, LSAPs may relax fiscal discipline and create distortions in asset allocation by discouraging longer-term investment, as term premiums are reduced, and all the more so if LSAPs have persistent effects. A large quantity of excess reserves also reduces activity in the money market and thus market discipline exercised through banks' monitoring of each other (Bindseil, 2016). The central bank may also crowd out the provision of safe assets by the private sector if it conducts LSAPs in normal times and create moral hazard by intervening to stabilise markets in unsafe assets, as market participants may then increase their risk-taking. Among potential financial costs, there are risks of losses for the central bank, both if it purchases unsafe assets and when it raises interest rates, especially after a long period of low rates, as the remuneration of reserves may then become higher than that of its assets. Losses could also force the central bank to ask for fiscal support, thus potentially endangering its independence. Particularly in case of losses arising from the purchase of unsafe assets, the central bank's independence may be called into question for it having played a fiscal role. More generally, in the face of proposals that central banks should intervene to purchase assets in order to stabilise markets (Farmer and Zabczyk, 2016), or lend directly to firms (Quint and Rabanal, 2017), one may wonder whether such a role, if deemed useful, could not be performed more effectively and more transparently by the Government or by a public investmentbank.

As recalled by Reis (2018), YCC can come in different forms (peg, ceiling, feedback rule for long rates, rule for the term spread, etc.) with different macroeconomic implications. For instance, Carlstrom et al. (2017) develop a model of segmented financial markets in which the net worth of financial institutions limits the degree of arbitrage across the term structure; they show that a policy that directly targets the term premium sterilises the real economy from shocks originating in the financial sector. Armenter (2018) finds that stabilising long-term interest rates can be useful when the ELB is reached and the inflation target is not fully credible - a situation reminiscent of that in Japan. However, Reis (2018) describes two historical episodes of central banks "going long" (the Fed's policy of putting a 2.5\% ceiling on the 10-year Treasury yield from 1942 to 1951, and the Bank of England's policy of pegging long-term interest rates throughout the 1960s) and concludes 
that these policies for the most part fail to keep inflation under control. Furthermore, in normal times, YCC involves the same costs as LSAPs.

4.2.2. Should other UMP instruments be introduced? Two other UMP instruments that have been suggested are "helicopter money" and the elimination of the ELB.

First, Friedman (1969) suggested that the central bank could have recourse to "helicopter drops" of money as a way out of a liquidity trap, using its capacity to issue the legal currency as an instrument of fiscal policy. By committing never to withdraw the increase in reserves resulting from the return of currency to the central bank after it has been used by the public for spending purposes and then deposited by merchants with banks, the central bank would permanently relax the government budget constraint. This idea has been taken up as a way of making "deflation, inflation below target, 'lowflation', 'subflation', liquidity trap and the deficient demand-driven version of secular stagnation (...) unnecessary" (Buiter, 2014). However, Borio and Zabai (2016) show that this can be achieved in only two ways: either the central bank does not pay interest on reserves and this amounts to taxing the banking sector, or it sets interest rates forever at zero, foregoing the ability to implement monetary policy. Furthermore, by taking on a fiscal task, the central bank would create the perception of falling under "fiscal dominance" and erode the public's confidence in the currency it issues.

Second, various proposals have been made to eliminate the ELB, although authors generally do not suggest abolishing cash, as this would be illiberal and unpopular. Rogoff (2017) proposes withdrawing large-denomination banknotes in order to increase the cost of storage of currency. However, this does not properly eliminate the ELB but rather lowers it. Buiter (2010), Agarwal and Kimball (2015), Pfister and Valla (2018) and Assenmacher and Krogstrup (2018) suggest following Eisler's (1932) proposal of introducing an exchange rate, in the form of a crawling peg, between the numéraire and the currency. As the currency would then depreciate in periods of negative interest rates (NIRs), this would allow pass-through of the negative policy rate to banks' deposit and loan rates. It would thus avoid hurting bank profitability and bank lending, all the more so as periods of NIRs would likely be shortened in comparison with the present ELB situation and accompanied by a steepening of the yield curve, and possibly also the need for LSAPs altogether (Pfister and Valla, 2018). 


\section{REFERENCES}

Abdih Y., Lin L., and Paret A.-C. (2018), "Understanding Euro Area Inflation Dynamics: Why So Low for So Long?", Working Paper 18/188, International Monetary Fund.

Acharya V., Eisert T., Eufinger C., Hirsch C. (2019), "Whatever It Takes: The Real Effects of Unconventional Monetary Policy", Review of Financial Studies, 32, 3366-3411.

Adrian T., Liang N. (2018), "Monetary Policy, Financial Conditions, and Financial Stability", International Journal of Central Banking, 14, 73-131.

Agarwal R., Kimball M. (2015), "Breaking Through the Zero Lower Bound", Working Paper WP/15/224, International Monetary Fund.

Altavilla C., Boucinha M., Peydro J.-L. (2018), "Monetary policy and bank profitability in a low interest rate environment", Economic Policy, 33, 531-586.

Altavilla C., Burlon L., Giannetti M., Holton S. (2019), "Is there a Zero Lower Bound? The Effects of Negative Policy rates on Banks and Firms", Working Paper 2289, European Central Bank.

Andrade P., Gali J., Le Bihan H., Matheron J. (2019), "The optimal inflation target and the natural rate of interest", BPEA Conference Draft, Fall.

Andrade P, Breckenfelder J, De Fiore F, Karadi P, Tristani O. (2016), "The ECB's asset purchase pro- gramme: an early assessment", Working Paper 1956, European Central Bank.

Angeletos G.-M., Lian C. (2018), "Forward Guidance without Common Knowledge", American Economic Review, 108, 2477-2512.

Armenter R. (2018), "The Perils of Nominal Targets", Review of Economic Studies, 85, 50-86.

Armenter R., Lester B. (2017), "Excess reserves and monetary policy implementation", Review of Economic Dynamics, 23, 212-235.

Arteta C., Kose M. A., Stocker M., Taskin T. (2016), "Negative Interest Rate Policies: Sources and Implications", Discussion Paper DP11433, Centre for Economic Policy Research.

Assenmacher K., Krogstrup S. (2018), "Monetary Policy with Negative Interest Rates: Decoupling Cash from Electronic Money", Working Paper WP/18/191, International Monetary Fund.

Ball L. (2014), "The Case for a Long-Run Inflation Target of Four Percent", Working Paper WP/14/92, International Monetary Fund.

Bank for International Settlements (2015), Regulatory change and monetary policy, CGFS Papers No 54 .

Bauer M. D., Neely C. J. (2014), "International channels of the Fed's unconventional monetary policy", Journal of International Money and Finance, 44, 24-46.

Baumeister C., Benati L. (2013), "Unconventional Monetary Policy and the Great Recession: Estimating the Macroeconomic Effects of a Spread Compression at the Zero Lower Bound", International Journal of Central Banking, 9, 165-212. 
Bech M., Keister T. (2017), "Liquidity regulation and the implementation of monetary policy", Journal of Monetary Economics, 92, 64-77.

Bech M., Klee E. (2011), "The mechanics of a graceful exit: Interest on reserves and segmentation in the federal funds market", Journal of Monetary Economics, 58, 415-431.

Bernanke B. (2014), "Central Banking after the Great Recession: Lessons Learned and Challenges Ahead", Remarks at The Brookings Institution.

Bernanke B. (2017), "Monetary Policy in a New Era", paper for the Conference on Rethinking Macroeconomic Policy, Peterson Institute, Washington DC, October 12-13.

Bhattarai S., Neely C. (2018), "An Analysis of the Literature on International Unconventional Monetary Policy", Working Paper 2016-021C, Federal Reserve Bank of St. Louis.

Binsdeil U. (2016), "Evaluating monetary policy operational frameworks", in Designing Resilient Monetary Policy Frameworks for the Future, Jackson Hole Economic Policy Symposium, Federal Re- serve Bank of Kansas City, 179-277.

Blanchard O., Dell'Ariccia G., Mauro P. (2010), "Rethinking macroeconomic policy", Journal of Money, Credit and Banking, 42, 199-215.

Blanchard O. (2016), "The US Phillips Curve: Back to the 60s?", Policy Brief 16-1, Peterson Institute for International Economics.

Bletzinger T., Wieland V. (2017), "Lower for longer": The case of the ECB", Economics Letters, 159, 123-127.

Blinder A., Ehrmann M., de Haan J., Jansen D.-J. (2017), "Necessity as the mother of invention: monetary policy after the crisis", Economic Policy, 32, 707-755.

Blinder A. (2018), "Through a Crystal Ball Darkly: The Future of Monetary Policy Communication", American Economic Review: AE A Papers and Proceedings, 108, 567-571.

Bonam D., Lukkezen J. (2019), "Fiscal and Monetary Policy Coordination, Macroeconomic Stability, and Sovereign Risk Premia", Journal of Money, Credit and Banking, 51, 581-616.

Bonis B., Ihrig J., Wei M. (2017), "The Effect of the Federal Reserve's Securities Holdings on Longerterm Interest Rates", FEDS Notes, Board of Governors of the Federal Reserve System, April 20, 2017.

Borio C., Gambacorta L. (2017), "Monetary policy and bank lending in a low interest rate environment: Diminishing effectiveness?", Journal of Macroeconomics, 54, 217-231.

Borio C., Lowe P. (2002), "Asset prices, financial and monetary stability: exploring the nexus", Working Paper 114, Bank for International Settlements.

Borio C., Zabai A. (2016), "Unconventional monetary policies: a re-appraisal", Working Papers 570, Bank for International Settlements.

Borio C., Zhu H. (2012), "Capital regulation, risk-taking and monetary policy: A missing link in the transmission mechanism?", Journal of Financial Stability, 8, 236-251.

Brainard L. (2017), Remarks on Bernanke (2017). 
Breedon F. (2018), "On the transactions costs of UK quantitative easing", Journal of Banking and Finance, 88, 347-356.

Brunnermeier M. K., Koby Y. (2018), "The Reversal Interest Rate", Mimeo, Princeton University.

Buiter W. H. (2010), "Negative nominal interest rates: Three ways to overcome the zero-lower bound", North American Journal of Economics and Finance, 20, 213-238.

Buiter W.H. (2014), "The Simple Analytics of Helicopter Money: Why It Works - Always", Discussion Paper DP9998, Centre for Economic Policy Research.

Caballero R. J., Farhi E., Gourinchas P.-O. (2017), "The Safe Assets Shortage Conundrum", Journal of Economic Perspectives, 31, 29-46.

Campbell J., Evans C., Fisher J., Justiniano A. (2012), "Macroeconomic Effects of FOMC Forward Guidance", Brookings Papers on Economic Activity, 1, 1-80.

Carlstrom C. T., Fuerst T. S., Paustian M. (2017), "Targeting Long Rates in a Model with Segmented Markets", American Economic Journal: Macroeconomics, 9, 205-242.

Cecchetti S., Genberg H., Wadhwani S. (2002), "Asset Prices in a Flexible Inflation Targeting Framework", Working Papers 8970, National Bureau of Economic Research.

Chen H, Curdia V, Ferrero A. (2012), "The Macroeconomic Effects of Large-scale Asset Purchase Programmes", Economic Journal, 122: F289-F315.

Claessens S., Coleman N., Donnelly M. (2018), "Low-For-Long" interest rates and banks' interest margins and profitability: Cross-country evidence", Journal of Financial Intermediation, 35, 1-16.

Cole J. C. (2018), "The effectiveness of central bank forward guidance under inflation and price-level targeting", Journal of Macroeconomics, 55, 146-161.

Coeuré B. (2016), "Assessing the implications of negative interest rates", Speech at the Yale Financial Crisis Forum, Yale School of Management, New Haven, 28 July.

Coeuré B. (2018a), "The persistence and signalling power of central bank asset purchase programmes", Speech at the US Monetary Policy Forum, New York City, 23 February.

Coeuré B. (2018b), "The future of central bank money", European Central Bank, Speech at the Inter- national Center for Monetary and Banking Studies, Geneva, 14 May.

Coeuré B. (2018c), "Monetary policy and climate change", Speech at the Conference on "Scaling up Green Finance", organised by the Network for Greening the Financial System, the Deutsche Bundesbank and the Council on Economic Policies, Berlin, 8 November.

Coibion O., Gorodnichenko Y, Wieland J. (2012), "The Optimal Inflation Rate in New Keynesian Models: Should Central Banks Raise their Inflation Targets in Light of the ZLB?", Review of Economic Studies, 79, 1371-1406.

Corbae D., Levine R. (2018), "Competition, Stability, and Efficiency in Financial Markets", Paper for the Jackson Hole Economic Symposium, Working Paper, Haas School of Business, University of California, Berkeley, 14 September. 
Curdia V. (2019), "How Much Could Negative Rates Have Helped the Recovery?", Economic Letter 2019-04, Federal Reserve Bank of San Francisco.

Deborteli D., Kim J., Lindé J., Nunes R. (2018), "Designing a Simple Loss Function for Central Banks: Does a Dual Mandate Make Sense?", Economic Journal, forthcoming.

Dell'Ariccia G., Rabanal P., Sandri D. (2018), "Unconventional Monetary Policies in the Euro Area, Japan, and the United Kingdom", Journal of Economic Perspectives, 147-172.

Del Negro M., Giannoni M., Patterson C. (2015), "The Forward Guidance Puzzle", Staff Reports 574, Federal Reserve Bank of New York.

Demiralp S., Eisenschmidt J., Vlassopoulos T. (2019), "Negative interest rates, excess liquidity and retail deposits: banks' reaction to unconventional monetary policy in the euro area", Working Paper 2283, European Central Bank.

De Santis R. A. (2019), "Redenomination Risk", Journal of Money, Credit and Banking, forthcoming. Drumetz F., Pfister C, Sahuc J.-G. (2015), Politique monétaire, 2nd edition, de Boeck.

Duffie D., Krishnamurthy A. (2016), "Pass-Through Efficiency in the Fed's New Monetary Policy Setting", in Designing Resilient Monetary Policy Frameworks for the Future, Jackson Hole Economic Policy Symposium, Federal Reserve Bank of Kansas City, 21-101.

Durand C., Villemot S. (2016), "Balance Sheets after the EMU: An Assessment of the Redenomination Risk", Working Paper 2016-31, Observatoire français des conjonctures économiques.

Eggerston G. B., Juelsrud R. E., Summers L. H., Wold E. G. (2019), "Negative Nominal Interest Rates and the Bank Lending Channel", Working Paper 25416, National Bureau of Economic Research.

Engen EM, Laubach T, Reifschneider DL. (2015), "The Macroeconomic Effects of the Federal Reserve's Unconventional Monetary Policies", Finance and Economics Discussion Series 2015-5, Board of Governors of the Federal Reserve System (U.S.).

Eisler R. (1932), Stable Money: The Remedy for the Economic World Crisis - A Programme of Financial Reconstruction for the International Conference, 1933.

Erikson H., Vestin D. (2019), "Pass-through at Mildly Negative Policy Rates: The Swedish Case", Sveriges Riksbank Staff Memo, January.

Falagiarda M., Reitz S. (2015), "Announcements of ECB conventional programs: Implications for sovereign spreads of stressed euro area countries", Journal of International Money and Finance, 53, 276295.

Farmer R., Zabczyk P. (2016), "The Theory of Unconventional Monetary Policy", Working Paper 22135, National Bureau of Economic Research. 
Ferrando A., Popov A., Udell G. (2019), "Do SMEs Benefit from Unconventional Monetary Policy and How? Microevidence from the Eurozone", Journal of Money, Credit and Banking, 51, 895-928.

Fève P., Garcia P., Sahuc J.-G. (2018), "State-Dependent Risk Taking and the Transmission of Monetary Policy Shocks", Economics Letters, 164, 10-14.

Filardo A., Hofmann B. (2014), "Forward guidance at the zero-lower bound", BIS Quarterly Review, March, 37-53.

Fratzscher M., Lo Duca M., Straub R. (2016), "On the International Spillovers of US Quantitative Easing", Economic Journal, 128(2), 330-377.

Friedman B. M. (1999), "The Future of Monetary Policy: The Central Bank as an Army with Only a Signal Corps?", International Finance, 2, 321-338.

Friedman M. (1969), "The Optimum Quantity of Money", in The Optimum Quantity of Money and Other Essays, Chapter 1, Aldine Publishing Company, Chicago.

Gagnon J., Raskin M., Remache J., Sack B. (2011), "The Financial Market Effects of the Federal Reserve's Large-Scale Asset Purchases", International Journal of Central Banking, 7(1), 3-43.

Gertler M. (2017), "Rethinking the Power of Forward Guidance: Lessons from Japan", Discussion Paper 2017-E-8, Institute for Monetary and Economic Studies, Bank of Japan.

Gertler M, Karadi P. (2013), "QE 1 vs. 2 vs. 3...: A Framework for Analyzing Large-Scale Asset Purchases as a Monetary Policy Tool", International Journal of Central Banking, 9, 5-53.

Gibson H. D., Hall S. G., Tavlas G. S. (2016), "The effectiveness of the ECB's asset purchase programs of 2009 to 2012", Journal of Macroeconomics, 47, 43-57.

Girotti M. (2019), "How Monetary Policy Changes Bank Liability Structure and Funding Cost", Oxford Economic Papers, forthcoming.

Goodhart C. A. (2017), "A Central Bank's Optimal Balance Sheet Size?", Discussion PaperDP12272, Centre for Economic Policy Research.

Greenlaw D., Hamilton J. D., Harris E., West K. D. (2018), "A Skeptical View of the Impact of the Fed's Balance Sheet", Working Paper 24687, National Bureau of Economic Research.

Greenwood R., Hanson S. G., Rudolph J. S., Summers L. H. (2016), "Debt management conflicts between the U.S. Treasury and the Federal Reserve", in The \$13 Trillion Question: How America Manages Its Debt, edited by David Wessel, Brookings Institution Press, 43-75.

Greenwood R., Hanson S. G., Stein J. (2016), "The Federal Reserve’s Balance Sheet as a FinancialStability Tool", in Designing Resilient Monetary Policy Frameworks for the Future, Jackson Hole Economic Policy Symposium, Federal Reserve Bank of Kansas City, 335-397.

Gust C., Herbst E., Lopez-Salido D., Smith M. E. (2017), "The Empirical Implications of the Interest- Rate Lower Bound", American Economic Review, 107(7), 1971-2006.

Hagedorn M., Luo J., Manovskii I., Mitman K. (2019), "Forward Guidance", Jounnal of Monetary Economics,102, 1-23. 
Hamilton J. D., Wu C. (2012), "The effectiveness of alternative monetary policy tools in a zero lower bound environment", Journal of Money, Credit and Banking, 44(S1), 3-46.

Hartmann P., Smets F. (2018), "The first twenty years of the European Central Bank: monetary policy", BPEA Conference Draft, Fall.

Heider F., Saidi F., Schepens G. (2019), "Life below zero: bank lending under negative policy rates", Review of Financial Studies, 32, 3728-3761.

Holston K., Laubach T., Williams J. (2017), "Measuring the Natural Rate of Interest: International Trends and Determinants", Journal of International Economics, S59-S75.

International Monetary Fund (2017), "Negative Interest Rate Policies-Initial Experiences and Assessments", Policy Paper, March 13.

Jorda O., Marti C., Nechio F., and Tallman E. (2019), "Inflation: Stress-Testing the Phillips Curve", Economic Letter 2019-05, Federal Reserve Bank of San Francisco.

Keister T. (2019), "The interplay between liquidity regulation, monetary policy implementation and financial stability", Global Finance Journal, 39, 30-38.

Kiley M. T. (2015), "Low Inflation in the United States: A Summary of Recent Research", Federal Reserve Board, FEDS Notes, November 23.

Kiley M. T., Roberts J. M. (2017), "Monetary Policy in a Low Interest Rate World", Brookings Papers on Economic Activity, 1, 317-397.

Klein M. (2020), "Implications of negative interest rates for the net interest margin and the lending of euro area banks", Working Paper 848, Bank for International Settlements.

Kockerols T., Kok K. (2019), "Leaning against the wind: macroprudential policy and the financial cycle", Working Paper 2223, European Central Bank.

Krishnamurthy A., Nagel S., Vissing-Jorgensen A. (2018), "ECB Policies Involving Government Bond Purchases: Impact and Channels", Review of Finance, 1, 1-44.

Krishnamurthy A., Vissing-Jorgensen A. (2011), "The Effects of Quantitative Easing on Interest Rates: Channels and Implications for Policy", Brookings Papers on Economic Activity, 2, 215-265.

Kuttner K. N. (2018), "Outside the Box: Unconventional Monetary Policy in the Great Recession and Beyond", Journal of Economic Perspectives, 32, 121-146.

Laubach T., Williams J. C. (2016), "Measuring the natural rate of interest redux", Business Economics, 51(2), 57-67.

Levieuge G. (2019), "La politique monétaire doit-elle être utilisée à des fins de stabilité financière ?", Revue Française d'Economie, 3/vol XXXIII, 63-104.

Levieuge G., Sahuc J.-G. (2020), "Monetary Policy Transmission with Downward Interest Rate Rigidity", mimeo, Banque de France.

Logan L. K. (2018), "Operational Perspectives on Monetary Policy Implementation: Panel Remarks on "The Future of the Central Bank Balance Sheet", Remarks at the Policy Conference on 
Currencies, Capital, and Central Bank Balances, Hoover Institution, Stanford University, Stanford, California, Federal Reserve Bank of New York, 4 May.

Lopez J. A., Rose A. K., Spiegel M. M. (2018), "Why Have Negative Nominal Interest Rates Had Such a Small Effect on Bank Performance? Cross Country Evidence", Working Paper 25004, National Bureau of Economic Research.

Lhuissier S. (2017), "Financial intermediaries' instability and euro area macroeconomic dynamics", European Economic Review, 98, 49-72.

Maliar L., Taylor J. B. (2018), "Forward Guidance: Is It Useful after the Crisis?", Discussion Paper DP13383, Centre for Economic Policy Research.

Marx M., Mojon B., Velde F. (2017), "Why Have Interest Rates Fallen Far Below the Return on Capital", Working Paper 630, Banque de France.

McKay A., Nakamura E., Steinsson J. (2016), "The Power of Forward Guidance Revisited", American Economic Review, 106, 3133-3158.

Moessner R., Jansen D.-J., de Haan J. (2017), "Communication about Future Policy Rates in Theory and Practice: A Survey", Journal of Economic Surveys, 31, 678-711.

Mouabbi S., Sahuc J.-G. (2019), "Evaluating the Macroeconomic Effects of the ECB's Unconventional Monetary Policies", Journal of Money, Credit and Banking, 51, 831-858.

Neely C. J. (2015), "Unconventional monetary policy had large international effects", Journal of Banking and Finance, 52, 101-111.

Pfister C., Valla N. (2018), "'New Normal' or 'New Orthodoxy'? Elements of a Central Banking Framework for the After-Crisis", Working Paper 680, Banque de France.

Potter S. (2018), "Confidence in the Implementation of U.S. Monetary Policy Normalization", Federal Reserve Bank of New York, Remarks at the 23rd EMEAP Governors Meeting, Manila, Philippines, 4 August.

Powell J. (2019), "Monetary Policy: Normalization and the Road Ahead", Speech at the 2019 SIEPR Economic Summit, Stanford Institute of Economic Policy Research, Stanford, California, 8 March. Quint D., Rabanal P. (2017), "Should Unconventional Monetary Policies Become Conventional?", Working Paper WP/17/85, International Monetary Fund.

Rajan R. (2012), "Is monetary policy the only game in town?", Word Economic Forum, 19 October. Reis R. (2018), "Central Banks Going Long", Discussion Paper DP12833, Centre for Economic Policy Research.

Rogoff K., (2017), "Dealing with Monetary Paralysis at the Zero Bound", Journal of Economic Perspectives, 31, 47-66.

Sahuc J.-G. (2016), The ECB's asset purchase programme: A model-based evaluation, Economics Letters, 145, 136-140. 
Sinha A. (2015), "FOMC Forward Guidance and Investor Beliefs", American Economic Review - AEA Papers and Proceedings, 105, 656-661.

Smets F. (2014), "Financial Stability and Monetary Policy: How Closely Interlinked?", International Journal of Central Banking, 10, 263-300.

Smith A. L., Becker T. (2015), "Has Forward Guidance Been Effective?", Economic Review, Q III, $57-$ 78, Federal Reserve Bank of Kansas City.

Stein J. (2012), "Monetary Policy as Financial-Stability Regulation", Quarterly Journal of Economics, 127, 57-95.

Sterk V., Tenreyo S. (2018), "The transmission of monetary policy through redistributions and durable purchases", Journal of Monetary Economics, 99, 124-137.

Svensson L. E. O. (1999), "Price-level targeting versus inflation targeting: a free lunch?", Journal of Money, Credit and Banking, 31, 277-295.

Svensson L. E. O. (2015), "Forward Guidance", International Journal of Central Banking, 11, 19-64.

Svensson L. E. O. (2017), "Cost-benefit analysis of leaning against the wind", Journal of Monetary Economics, 90, 193-213.

Swanson E. T. (2017), "Measuring the Effects of Federal Reserve Forward Guidance and Asset Purchases on Financial Markets", Working Paper 23311, National Bureau of Economic Research. Szczerbowicz U. (2015), "The ECB Unconventional Monetary Policies: Have They Lowered Market Borrowing Costs for Banks and Governments?", International Journal of Central Banking, 11, 91-127.

Taylor J. B. (1999), "Introduction", in Monetary Policy Rules, edited by J.B. Taylor, Chicago University Press, Chicago, 1-14.

Thornton D. L. (2017), "Effectiveness of QE: An assessment of event-study evidence", Journal of Macroeconomics, 52, 56-74.

Weale M, Wieladek T. (2016), "What are the macroeconomic effects of asset purchases?", Journal of Monetary Economics, 79, 81-93.

Williamson S. (2016), "Neo-Fisherism: A Radical Idea, or the Most Obvious Solution to the LowInflation Problem?", The Regional Economist, Federal Reserve Bank of St. Louis.

Woodford M. (2001), "Monetary Policy in the Information Economy", in Economic Policy for the Information Economy, Jackson Hole Economic Policy Symposium, Federal Reserve Bank of Kansas City, 297-370.

Woodford M. (2016), "Quantitative Easing and Financial Stability", Working Paper 22285, National Bureau of Economic Research.

Wu C., Xia D. (2016), "Measuring the Macroeconomic Impact of Monetary Policy at the Zero Lower Bound", Journal of Money, Credit and Banking, 48, 253-291. 